RESEARCH ARTICLE

\title{
Extraction of pure metallic nickel from ores and plants at Ussangoda, Sri Lanka
}

\author{
K. Tennakone*, M.K.I. Senevirathna and K.V.W. Kehelpannala \\ Institute of Fundamental Studies, Hantana Road, Kandy.
}

\begin{abstract}
Samples of serpentine from Ussangoda in the Hambantota District were found to contain 2-3\% nickel of minable quality. Laterite from the same location contained $0.4 \%$ nickel. Nickel and several other metals in these rocks dissolved almost completely into hot $50 \%$ sulphuric acid. Nickel, cobalt, and any zinc that form complexes with ammonia were separated into the aqueous phase by addition of excess ammonia and filtration of precipitated hydroxides of magnesium, iron, manganese, chromium and aluminium. Acidification of the filtrate yielded a solution of nickel sulphate admixed with small amounts of cobalt and zinc. Electrolysis of the filtrate with a conducting tin oxide glass cathode after removal of cobalt yielded pure nickel. The process can also produce nickel ammonium sulphate. Extraction of metallic nickel from a nickel hyperaccumulating plant growing in Ussangoda is also demonstrated. The possibility of nickel mining in Sri Lanka and the importance of petrological, geochemical and ecological studies of the serpentine area at Ussangoda and other localities are discussed.
\end{abstract}

Keywords: Nickel hyperaccumulators, nickel mining, nickel ores, serpentine, ultramafics.

\section{INTRODUCTION}

A visit to Ussangoda, a plateau in the southern coast of Sri Lanka, arouses curiosity because of the scenic beauty of the surroundings and the peculiar geology and ecology of the region. The unique types of rocks occurring in the area are ferro-laterite, serpentines and ochre red soil quite rich in ferric oxide, clearly a weathering product of ferro-laterite. The topmost portion of the laterite cover is also rich in nodules containing excessive amounts of iron and more chromium compared to the laterite. As the rocks abundantly found are metamorphosed ultramafic material and products of their weathering, a magma intrusion seems to be the more plausible cause for formation of the Ussangoda complex. Most rocks at Ussangoda contain significant amounts of nickel and lesser quantities of cobalt, manganese and chromium. The vegetation around the plateau conspicuously manifests signs of metal toxicity. A region of nearly $1 \mathrm{~km}^{2}$ facing the ocean is devoid of any vegetation except very few species of herbs. A thicket of dwarfed species rising up to about $2 \mathrm{~m}$ covers the region beyond the bare patch (Figure1).

Nickel is mined from sulphide ores, nickel-ferrolaterite and serpentine ${ }^{1-3}$. Although the sulphide ores are the preferred sources of this metal, more than $40 \%$ of the world's supply of nickel comes from laterites and serpentines. Production of nickel has increased eightfold from 1950 to $2000^{2}$. It is an expensive item in the world metal market extensively used as an alloying agent, a component of magnetic materials and for electroplating. Russia, Canada, Australia, New Caledonia, Cuba, Indonesia and China produce over eighty percent of the world's nickel ${ }^{1}$. Until recent times nickel supply matched the demand maintaining reasonable prize per kiloton. During the past few years nickel prices have sharply escalated owing to voracious consumption of this commodity by the expanding metallurgical industries in China and India ${ }^{4}$. With the exhaustion of existing deposits, the demand for nickel seems to exceed the current production. The global demand for nickel and the present situation with regard to its manufacture opens up opportunities for countries possessing untapped nickel resources.

Our analysis of rocks from Ussangoda indicated that some samples of serpentinite contain 2-3\% nickel. Although the Ussangoda park, an area conserved as an archaeological site, should not be exploited for nickel mining, other regions in the country near Ginigalpellesa, Yodhagannwa, Udawalawe, Indikolapellesa, Rupaha and

${ }^{*}$ Corresponding author 
Katupotha have serpentine outcrops ${ }^{5-6}$ (Figure 2). Some of these localities lie along the boundary between the Wanni Complex (the newly defined Wanni Complex of Kehelpannala $^{7}$ ) and the Highland Complex suggesting a common cause of origin of the deposits (Figure 2). A high nickel concentration in serpentinite at Ginigalpellesa in the Udawalawe area has been reported by Dissanayake and Van Riel ${ }^{6}$ in 1978, the first published report on the occurrence of a mineral in Sri Lanka containing substantial amount of nickel. As tropical climates favour transformation of mafic and ultramafic rocks to secondary minerals such as serpentinites and laterites, regions around the boundary are expected to be rich in nickel and other metals ${ }^{8-10}$.

We have successfully extracted pure metallic nickel from samples of green serpentine collected from Ussangoda. In this note we describe a method for extraction of pure metallic nickel from Sri Lankan serpentine and laterite. The processes could also be directed to make nickel ammonium sulphate which is also a marketable product used in the electroplating industry. Nickel hyperaccumulating plants growing at Ussangoda were found to contain significant amounts of nickel. Extraction of metallic nickel from their biomass is also demonstrated. We believe that this is the first time the extraction of pure metallic nickel from Sri Lankan sources has been demonstrated. Investigation suggests possibilities of nickel mining industry in Sri Lanka

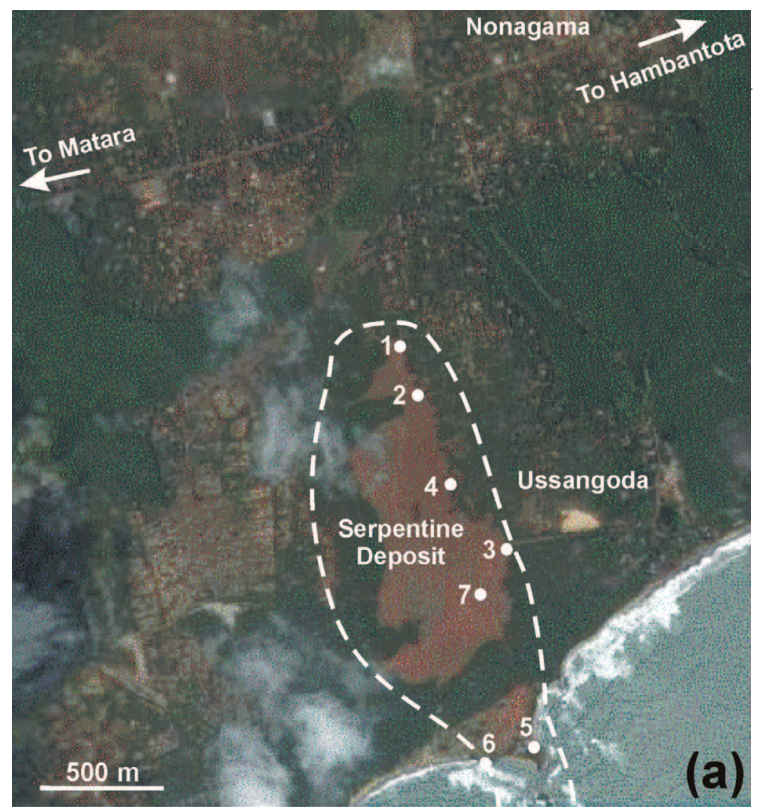

after a careful petrological survey and assessment of the environmental consequences of mining.

\section{METHODS AND MATERIALS}

Samples of serpentine pale green in colour, ferro-laterite, iron-rich nodules and ochre red top soil were collected from Ussangoda (Figure 1a shows the locations from which the samples were collected) taking every precaution to exclude organic and anthropogenic material. Rocks were pulverized, meshed to $297 \mu \mathrm{m}$ and dried at $110{ }^{\circ} \mathrm{C}$ to expel moisture. Powders $(10 \mathrm{~g})$ were digested with $50 \%$ sulphuric acid $(40 \mathrm{~mL})$ at $100{ }^{\circ} \mathrm{C}$ for $3 \mathrm{~h}$ and the insoluble residue was separated by filtration. Atomic absorption spectroscopy ${ }^{11}$ (Flame Atomic Absorption Spectrometer GBC 933A) was used to estimate Ni, Fe, $\mathrm{Co}, \mathrm{Cr}, \mathrm{Al}, \mathrm{Mn}, \mathrm{Zn}, \mathrm{Pb}$ and $\mathrm{Cd}$ concentrations in the filtrate. The instrument was calibrated using authentic standards (Fluka). For confirmation, a nickel standard solution was also prepared by dissolving known weight of pure metallic nickel in aqua regia. Samples $(25 \mathrm{~mL})$ of the filtrate prepared by the same technique were treated with excess ammonia to precipitate iron, magnesium, aluminium, manganese, and chromium as hydroxides and exposed to air for converting any ferrous iron to ferric. Insoluble precipitate was separated by filtration. Filtrate was neutralized with conc. sulphuric acid to a $\mathrm{pH}$ of 6.5 . The $\mathrm{Ni}$ and other metal concentrations in the filtrate were again estimated by atomic absorption spectroscopy. The solid residue was digested with HF and the extract was tested for the metals. For confirmation of atomic absorption spectroscopic analysis, nickel was also estimated gravimetrically using dimethylglyoxime as follows ${ }^{11}$. An ammonical extract of the ores, prepared as described earlier, is acidified to adjust the $\mathrm{pH}$ to a value within the

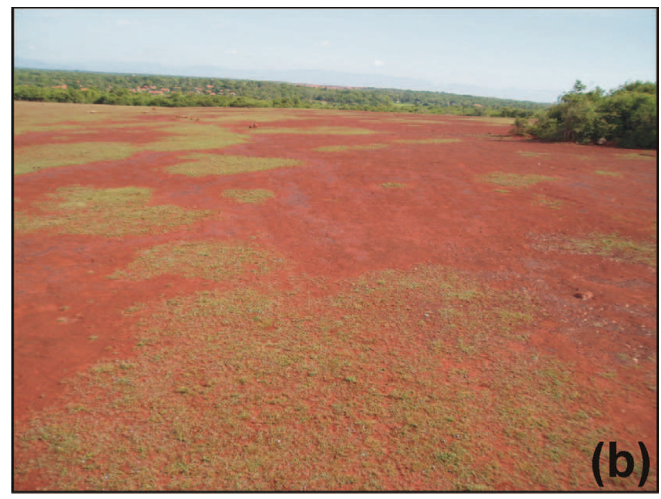

Figure 1: (a) Satellite image (downloaded from Google Earth) showing the Ussangoda serpentine deposit. The white broken line demarcates the boundary of the deposit. Numbers indicate the locations from which the samples of serpentine were collected. (b) Photograph showing the red soil overlaying the deposit. 
range 9-10 and a solution of dimethylglyoxime (10 g in $100 \mathrm{~mL}$ ) is gradually added to precipitate the scarlet red Ni-dimethylglyoxime complex which is washed (water and alcohol), dried and weighed. To extract metallic nickel, the final filtrate was electrolyzed using a conducting tin oxide glass cathode and platinum or carbon anode. Samples of metallic nickel deposited on the cathode were dissolved in nitric acid and tested for $\mathrm{Ni}$, $\mathrm{Co}, \mathrm{Fe}, \mathrm{Zn}, \mathrm{Cr}$ and $\mathrm{Cd}$ by atomic absorption spectroscopy. Portions of the filtrate were also concentrated and left for two to three days to crystallize nickel ammonium sulphate.

The following procedure was used to extract nickel from plants growing at Ussangoda. Biomass excluding the roots was washed with distilled water to remove adhered soil particles, dried at $105{ }^{\circ} \mathrm{C}$ in air for $1 \mathrm{~h}$ and ground to a fine powder and ashed in an oven. The powder was mixed with conc. sulphuric acid (1.5 $\mathrm{mL}$ per $\mathrm{g}$ of ash), and the mixture was heated for about $10 \mathrm{~min}$ to char any remaining organic matter, diluted with water, boiled and the residue was separated by filtration. Ammonia was added to adjust the $\mathrm{pH}$ to 11 and the solution was aerated by vigorous stirring. The gelatinous precipitate formed was removed by filtration and $\mathrm{pH}$ of the filtrate was reduced to 6.5 by addition of conc. sulphuric acid. Nickel was extracted electrolytically from this solution using a conducting tin oxide glass cathode and a carbon counter electrode. A quick qualitative test for detection of nickel in plants at Ussangoda was conducted as follows. Plant tissue (few milligrams) was charred by heating with few drops of conc. sulphuric acid. The product was diluted to about $5 \mathrm{~mL}$, made alkaline with ammonia and the scarlet colouration observed after addition of few drops of dimethylglyoxime solution in alcohol indicated the presence of nickel.

\section{RESULTS AND DISCUSSION}

Results of the analysis of rock samples, i.e., serpentine, lateritic nodules and ferro-laterite from Ussangoda, extracted into sulphuric acid as described in the previous section are presented in Table 1 . A Ni percentage of $3 \%$ in serpentine more than suffices the concentration generally accepted for commercial mining ${ }^{1,8}$. Of the samples of serpentine analyzed, the highest Ni percentage we could observe was $3.2 \%$ (mean of 4 measurements, samples collected from the point marked 7 in Figure 1a). The Ni content of the other samples was in the range $1.9-2.8 \%$. Serpentines containing around $2 \% \mathrm{Ni}$ have also been found in the Walawe area ${ }^{6}$. Generally, nickliferrous serpentines mined from different points of the same deposit show high degree of variation of the Ni content as the local weathering profile determines Ni separation ${ }^{8}$.
Laterite samples (up to a depth of $\sim 15 \mathrm{~cm}$ ) we examined had $0.4-0.5 \% \mathrm{Ni}$, and the top soil also contained similar amounts of $\mathrm{Ni}$. Approximately $0.4 \% \mathrm{Ni}$ in the ferro-laterite and the red top soil falls slightly below the level of $\mathrm{Ni} \%$ in an ore normally used for commercial processing. Deposits located deeper, which we have not examined, may be more concentrated. Compared to serpentine, lateritic nodules contain higher amounts of chromium and cobalt $(0.6 \% \mathrm{Cr}$ and $0.07 \% \mathrm{Co})$.

The residue left after sulphuric acid treatment of the serpentine samples was white in colour ( $46 \%$ by wt. consisting of magnesium silicate and silica) and their HF extracts did not give signals for any of the metals listed in the Table 1. This observation indicates that almost all nickel passes into the solution phase during the reaction with sulphuric acid. The Ussangoda serpentine contains much less iron, i.e., 3-4 \%, compared to some of the well known deposits where the iron content exceeds $10 \%$. Ores with lesser quantities of iron serve better for extraction of nickel as removal of iron consumes energy and costly chemicals and also adds more to pollution. A study of the Ussangoda serpentine will also shed light into the mechanism of nickel concentration and iron depletion in the rock by the weathering processes. Presumably, higher temperature and water in the environment created by heavy rainfall have assisted more efficient separation.

The sulphuric acid treatment also dissolves $\mathrm{Mg}$ and rare earths into the solution phase during the acid treatment, the percentages of which we have not estimated. When the acid extract is treated with excess ammonia, $\mathrm{Mg}^{2+}, \mathrm{Fe}^{3+}, \mathrm{Fe}^{2+}, \mathrm{Al}^{3+}, \mathrm{Mn}^{2+}, \mathrm{Cr}^{3+}$, and rare earths precipitate as hydroxides. $\mathrm{Ni}^{2+}, \mathrm{Co}^{2+}, \mathrm{Zn}^{2+}$ and any $\mathrm{Cu}^{2+}, \mathrm{Cd}^{2+}$ and $\mathrm{Pb}^{2+}$ that make complexes with ammonia pass into the solution phase. In the presence of a large excess of ammonia, small quantities of $\mathrm{Al}^{3+}, \mathrm{Cr}^{3+}$ and $\mathrm{Fe}^{2+}$ tend to enter into the solution as aluminates, chromites

Table 1: Percentages of different metals extracted into sulphuric acid from a given weight of serpentine (sample 7) from nodules and laterite.

$\begin{array}{cccc}\text { Metals } & \text { Serpentine }(\%) & \text { Nodules }(\%) & \text { Laterite }(\%) \\ \mathrm{Al} & 0.031 & 0.034 & 2.142 \\ \mathrm{Cr} & 0.040 & 0.570 & 0.079 \\ \mathrm{Ni} & 3.034 & 0.380 & 0.392 \\ \mathrm{Co} & 0.020 & 0.069 & 0.019 \\ \mathrm{Zn} & 0.005 & 0.015 & 0.007 \\ \mathrm{Fe} & 3.772 & 25.575 & 7.380 \\ \mathrm{Cd} & <0.001 & <0.001 & <0.001 \\ \mathrm{Cu} & 0.001 & 0.002 & 0.004 \\ \mathrm{Mn} & 0.035 & 0.186 & 0.065 \\ \mathrm{~Pb} & <0.001 & <0.001 & <0.001\end{array}$


and ferrates. Oxidation of $\mathrm{Fe}^{2+}$ in the precipitate to $\mathrm{Fe}^{3+}$ prevents the entry of $\mathrm{Fe}$ to the ammonical solution. Removal of Fe is important to avoid its deposition along with Ni during electrolysis. However, small quantities of $\mathrm{Al}, \mathrm{Cr}$ and $\mathrm{Zn}$ do not interfere with the final step of electrolytic extraction of nickel. Leaching of Co can also be prevented, if the ammonical solution is oxidized with hypochlorite prior to filtration as cobaltic hydroxide is insoluble in ammonia. Vigorous aeration of the solution after addition of ammonia is found to be effective in removing a good portion of Co. Table 2 gives the percentage content of various metals in the ammonical extract.

Table 2: Percentages of different metals in a given weight of serpentine (sample 7) entering the ammonical solution after filtration of the precipitate. (Composition of the original solution before the addition of ammonia is given in Table 1).

$\begin{array}{cc}\text { Metal } & \text { Percentage (\%) } \\ \mathrm{Ni} & 3.000 \\ \mathrm{Fe} & <0.002 \\ \mathrm{Zn} & 0.007 \\ \mathrm{Cd} & <0.001 \\ \mathrm{Co} & 0.020 \\ \mathrm{Cu} & <0.001 \\ \mathrm{Mn} & 0.003 \\ \mathrm{~Pb} & <0.001 \\ \mathrm{Cr} & <0.001 \\ \mathrm{Al} & <0.001\end{array}$

Neutralization of the ammonical solution with conc. sulphuric acid to a $\mathrm{pH} \sim 6.5$ converts the nickel ammonium complex ion into $\mathrm{Ni}^{2+}$. Likewise the small amount of cobalt ammonium complex present transforms to $\mathrm{Co}^{2+}$ (i.e., solution now contains nickel sulphate, ammonium sulphate and a small quantity of cobalt sulphate). On electrolysis of this solution with a conducting tin oxide glass cathode and a carbon or platinum anode, nickel deposits on the conducting glass cathode. Use of a conducting glass cathode avoids contamination of nickel (which happens if an ordinary metal cathode is used). In a more practical situation conducting glass can be replaced by carbon or titanium electrode. When the samples of nickel deposited on conducting glass were dissolved in nitric acid and analyzed spectrophotometrically, the purity was found to be $\sim 100 \%$ within the detection limit.

Most plants growing at Ussangoda showed accumulation of readily detectable amounts of $\mathrm{Ni}$, and the highest concentration in Hybanthus enneaspermus (violacea) was found abundantly in the region devoid of the scrub. Although percentage of $\mathrm{Ni}$ in the herb showed wide variations depending

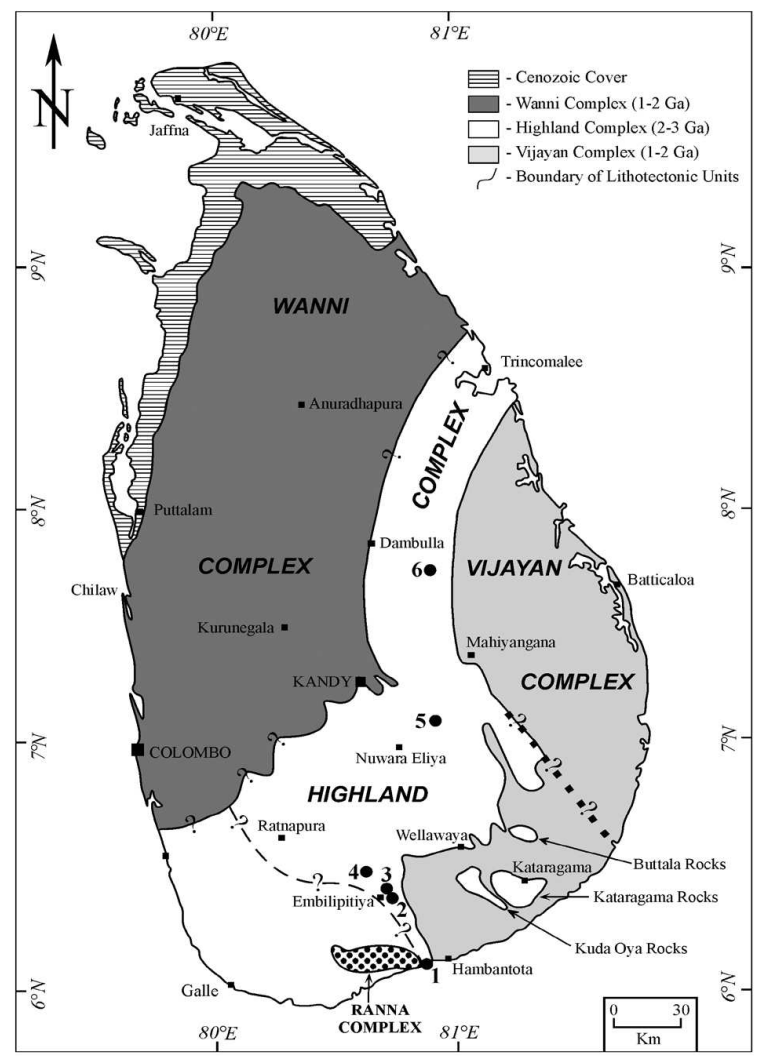

Figure 2: Lithotectonic map of Sri Lanka showing serpentinite occurrences. 1- Ussangoda, 2- Indikolapelessa, 3Ginigalpelessa, 4- Katupotha, 5- Rupaha, 6- Yodhaganawa. Note that the serpentine deposits at 1-4 lie close to the newly defined Wanni Complex/Highland Complex boundary of Kehelpannala ${ }^{7}$, whereas those at locations 5 and 6 are situated in the Highland Complex. Lithotectonic units and boundaries shown are after Kehelpannala ${ }^{7}$.

on the location of the plant, an extract prepared from about $20 \mathrm{~g}$ dry biomass enabled electrodeposition of metallic nickel on conducting tin oxide glass. Tests with dimethylglyoxime showed that quite a number of herbs and trees at Ussangoda contain accumulated nickel, possibly sufficient for extraction of the metal. Covers of lichens were also seen on the surface of serpentine rocks. Similar experiments indicated that these organisms also have high levels of accumulated nickel.

Although the Ussangoda serpentinite body was identified more than three decades ago, its geology has not yet been investigated. Our preliminary field investigations suggest that the deposit had originated from serpentinization of basic to ultramafic rocks. The 
Ussangoda deposit and similar serpentinite occurrences at Indikolapelessa, Ginigalpelessa and Katupotha seem to lie along the boundary between the Wanni Complex (the Wanni Complex of Kehelpannala ${ }^{7}$ ) and the Highland Complex of Sri Lanka (Figure 2). Although the most likely cause behind the formation of these deposits seems to be magmatic intrusions to the crust along the boundary, the possibility of involvement of an intercalated oceanic crust cannot be ruled out ${ }^{7}$. Minerals found in association with serpentine at Ussangoda, i.e., chert, chalcedony, agate, magnesite, graphite, and goethite, are products of serpentinization of ultramafics. The nickeliferous serpentinites at Ussangoda are overlain by ferro-laterite (about 1-2 m thick), ferruginous layer composed of pebbles and iron rich nodules, and the top red soil. A detailed study of the geology, petrology and geochemistry has already been undertaken by the authors to determine the origin and the economic importance of serpentinites in Sri Lanka.

\section{CONCLUSION}

Serpentine samples with nickel concentrations of the order $3 \%$ seems to be abundant in the Ussangoda plateau. However, an extensive petrological survey of serpentine areas in the country is needed to asses the extent of availability of the ore. The method we have proposed for extraction of nickel certainly needs modifications to render the process commercially viable. Cheaper raw materials such as lime may be substituted at some stages of the process. However, sulphuric acid and ammonia which we do not manufacture would remain indispensable ingredients of the process. Both these chemicals find other important applications, especially in the fertilizer sector. Development of a completely indigenous nickel industry in Sri Lanka may necessitate our own manufacture of sulphuric acid and ammonia. Nickel industry will also lead to environmental concerns which need to be studied carefully ${ }^{12-13}$. Sri Lanka could embark on small scale industry to produce nickel salts (e.g., nickel ammonium sulphate) and nickel anodes for the nickel electroplating industry in the country. Using solar based electricity for electrowinning of nickel should be seriously considered. An interesting possibility is electrolytic co-deposition of nickel and iron for production of magnetic films used in electronics. Such films constituted of pure nickel and iron will also find applications in spintronics and nanotechnology ${ }^{14-15}$.

Geochemical and ecological studies on ultramafic zones of Sri Lanka have other practical as well as fundamental implications. Apartfromnickel, theseregions could be rich in ores containing commercially viable quantities of other metals, notably cobalt and chromium. Both these metals are costly items in the world metal market.

The top soil in the Ussangoda plateau is exceptionally rich in $\mathrm{Ni}$, Co and $\mathrm{Cr}$, making it highly toxic to plants. Sea breeze seems to aggravate the situation further. It appears that hydrochloric acid released in hydrolysis of magnesium chloride in the sea breeze has acidified the soil solubilizing the toxic metals. Nevertheless, few plants survive in the almost nude patch facing the ocean and most severely exposed to the sea breeze. Metals-hyperaccumulating plants could be abundant at Ussangoda ${ }^{17-18}$ and other serpentine regions of the country. These hyperaccumulators of metals could find applications in environmental remediation of soils and phytomining ${ }^{18-19}$ (using plants to extract metals from soil). Phytomining, if developed, would be environmentally friendly, and in addition to metals they yield biomass for fuel. It is also important to determine whether metals in serpentine areas leach into the drinking water or enter the food chain through accumulating plants.

\section{Acknowledgment}

Authors thank the Director, Department of Archaeology for permitting collection of samples from Ussangoda. The field work of one of the authors (K.V.W.K.) was supported by the National Science Foundation Grant RG/2005/DMM/01. Authors also thank L.V. Ranaweera, A. Pathirana and S. Opatha for assistance granted to enable this investigation.

\section{References}

1. McCutcheon B. (2003). Canadian Minerals Year Book, Nickel. Department of Mines, Energy and Natural Resources, Canada, pp. 1-21.

2. Blainey G. (1994). The Rush That Never Ended: A History of Australian Mining. 4th Edition, Melbourne University Press, Melbourne.

3. Dakvi A.D., Bacon W.G. \& Osborne R.C. (2004). Past and future of nickel laterites. PDAC International Trade Show and Investors Exchange, Inco Ltd. Canada, March 7-10.

4. Flood C. (2006). Nickel spikes on short covering, Financial Times, August 18, 2006.

5. Rajakaruna N., Harris C.S. \& Towers G.H.N. (2002). Antimicrobial activity of plants collected from serpentine outcrops in Sri Lanka. Pharmaceutical Biology 40: 235 - 244.

6. Dissanayake C.B. \& Van Riel B.J. (1978). Petrology and geochemistry of a recently discovered nickeliferous serpentinite in Sri Lanka, Journal of the Geological Society of India 19: 464-471. 
7. Kehelpannala K.V.W. (2004). Arc accretion around Sri Lanka during the assembly of Gondwana. Gondwana Research 7: 1323-1328.

8. Guilbert J.M. \& Park (Jr) C.F. (1975). Geology of Ore Deposits pp. 985 Freeman, New York.

9. Norton S.A. (1973). Laterite and bauxite formation. Economic Geology. 68: 353-361.

10. Golightly J.P. (1981). Nickeliferrous laterite deposits, Economic Geology $75^{\text {th }}$ Anniversary Volume: 719-735 .

11. Jeffery P.G. \& Hutchison D. (1987). Chemical Methods of Rock Analysis. $3^{\text {rd }}$ Edition, Pergamon Press, London.

12. Beaumont T. (2005). Ramu Nickel Mine: A triple bottom failure? Briefing paper, Mineral Policy Institute Inc., Australia, September 2005.

13. Bird E.C.F, Dubois J.P. \& Iltis J.A. (1989). The impact of open and cast mining on rivers and coasts of New Caledonia. United Nations University Press, Tokyo.

14. Brenner A. (1967). Electrodeposition of Alloys. Volume 1, Academic Press, New York.

15. Spark E.R., de Oliveira L.S., da Rocha A.S., Pasa A.A., SaZangari B. \& Sartorelli M.L (2000). Thin films of $\mathrm{Fe}_{\mathrm{x}} \mathrm{Ni}_{1-\mathrm{x}}$ electroplated on silicon (100). Journal of
Magnetism and Magnetic Materials 4: 274-276.

16. Senevirathna A.S., Nandadasa H.G., Fernando W.S., Sanjeewanni H.H.V.M. \& Rajapaksa R.L.H.R. (2000). The Serpentine Vegetation of Ussangoda (Hambantota District) and Nickel Accumulating plant species, Sixtieth Annual Forestry and Environmental Symposium, Peradeniya, Sri Lanka, 29-30 December 2000.

17. Iqbal M.C., Kulasekara L., Rajakurana N. \& Iqbal S.S. (2006). Plant-soil relations of a serpentine site in the southern coast of Sri Lanka (Abstract). $5^{\text {th }}$ International Conference on Serpentine Ecology, Siena, Italy, 9-13 May 2006.

18. Brooks R.R. \& Robinson B.H. (1998). The potential use of hyperaccumulators and other plants for phytomining. In: Plants that hyperaccumulate heavy metals their role in phytoremediation, microbiology, archaeology, mineral exploration and phytomining. (Ed. R.R. Brooks) pp. 327 356. CAB, Cambridge, UK.

19. Chardot V., Massoura S.T., Echevarria G., Reeves R.D. \& Morel J.L. (2005). Phytoextraction potential of the nickel hyperaccumulator Laptolax emarginat and Bornmuellere tymphaea. International Journal of Phytomediation 7: 323-335. 